\title{
Linear Generator Used in Hybrid System Solar Biomass
}

\author{
Angelo José Junqueira Rezek ${ }^{1}$, Carlos Rocha ${ }^{1}$, Wladimir Cobas ${ }^{2}$, Electo E. S. Lora ${ }^{2}$, Paulo S. P. Correa Jr. ${ }^{2}$, \\ Osvaldo J. Venturini ${ }^{2}$, Rubenildo Andrade ${ }^{2}$, José C. Escobar ${ }^{2}$ and Marcelo Pirani ${ }^{2}$ \\ 1. ISEE (Instituto de Sistemas Elétricos e Energia), UNIFEI (Universidade Federal de Itajubá), Itajubá 37.500-903, Brazil \\ 2. IEM (Instituto de Engenharia Mecânica), UNIFEI (Universidade Federal de Itajubá), Itajubá 37.500-903, Brazil
}

\begin{abstract}
The aim of this paper is to present the linear generator (Stirling solar dish) in the context of a HSSB (hybrid system solar biomass), project P \& D (research and development P \& D 0041, in cooperation and partnership with CPFL—Light and Force Paulista Company-Campinas, Piratininga, S.P. Brazil). The other components of the system will be the solar ORC (organic Rankine cycle), the rotary Stirling and the biomass gasifier. The integration of the complete system will be described in the paper, and is projected to be hydraulic one.
\end{abstract}

Key words: Linear generator, Stirling solar dish, electric-hydraulic integration.

\section{Introduction}

Fig. 1 shows the linear generator of this HSSB (hybrid system solar biomass), projected to be constructed in a future laboratory in the field, ground, near of UNIFEI (Federal University of Itajubá).

The aim of the project is to design, build and test the hybrid system for converting energy, solar/biomass using Stirling motors, internal combustion motor, ORC (organic Rankine cycle) and integration, regulation/accumulation hydraulic/electrical system to distributed energy generation, which will be described hereafter. For this purpose, the HSSB must have:

- Internal combustion motor Otto cycle, using biomass gas from the fixed bed gasifier dual stage;

- External combustion motor, rotary Stirling cycle, with inverted furnace;

- External combustion motor, Stirling cycle, solar parabolic concentrator type;

- ORC, with cylindrical parabolic solar concentrator.

Besides the hybrid solar systems/biomass for power generation, the project includes: system integration, hydraulic/electrical generation for distributed energy generation.

\section{System Components}

This system intends to add solar and biomass energy, integrating two renewable (intermittent/solar-still/biomass), with accumulation/hydraulic-electric integration, creating a HSSB, to meet typical electricity demands, existing in distributed energy generation, and should allow contributing studies concerning the integration of this system to the interconnected power generation system . Fig. 2 shows the components of the system [1-11].

\section{Hydraulic System Integration and Accumulation of Energy for Electrical Generation}

Fig. 3 shows the proposed integration system. The first idea was to project all components with hydraulic integration, as shown in Fig. 3; but after studies, the more convenient, simple and applicable has been to decide to a hybrid hydraulic-electric integration, as shown in Fig. 4. In this arrangement, only the furnace Stirling, and gasifier has been projected to integrate the

Corresponding author: Angelo José Junqueira Rezek, Ph.D., titular professor, research field: electrical converters applied to control systems. E-mail: rezek@unifei.edu.br. 


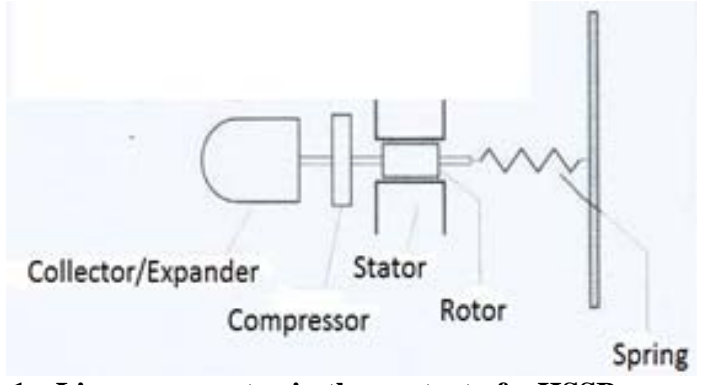

Fig. 1 Linear generator in the context of a HSSB.

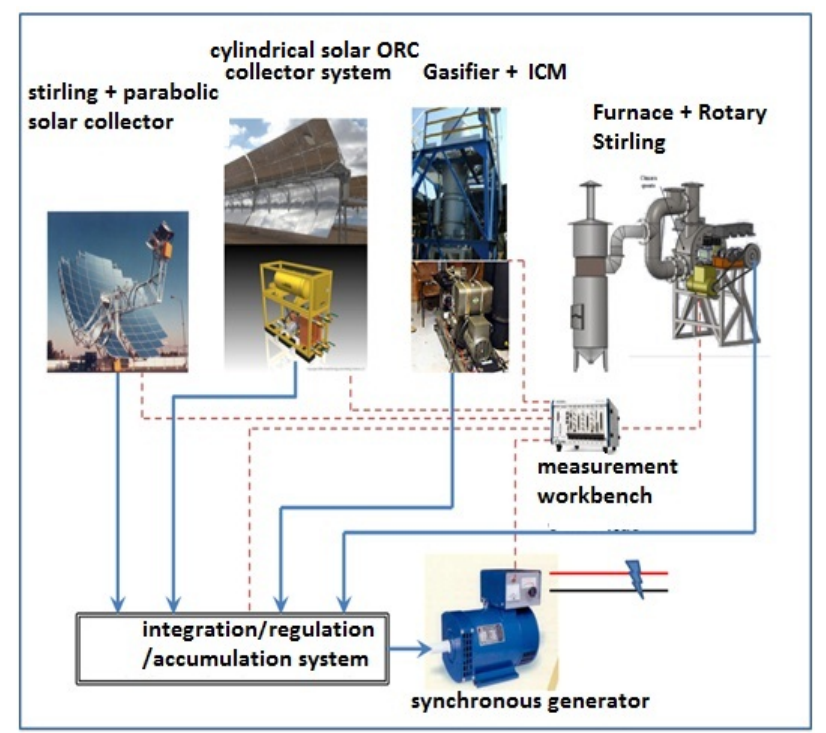

Fig. 2 Components of the system.

hydraulic integration, with aggregation of oil pumps, the other ones, as the ORC and Stirling solar dish, has been decided to compose the electric integration system, due to the more simplicity of this arrangement.

The strategy is delivering mechanical available energy for a fluid which could be, for instance oil. In this strategy, the idea is to accumulate the energy in a fluid by raising its pressure, so that each generating source triggers a pump or a compressor to increase the potential energy of the fluid. For conversion of potential energy into electrical energy, a turbine would be used driving an electrical generator. Hydrostatic transmission transmits power through the use of high pressure oil, typically pressures up to 340 bar. Fig. 5 shows the Stirling solar dish.

A set as described in Fig. 2 [12-24], it consists of a Stirling motor, a parabolic solar collector and a tracking system that aims to capture solar energy and propitiate its conversion into mechanical energy, to drive a linear generator whose capacity is to be defined, but must be about $1 \mathrm{kVA}$. The motor should be mounted at the focus of the parabola in order to receive heat from the sun, which will be concentrated using parabolic concentrator. Joint, motor and parabola shape must move in order to maximize the capture of solar energy.

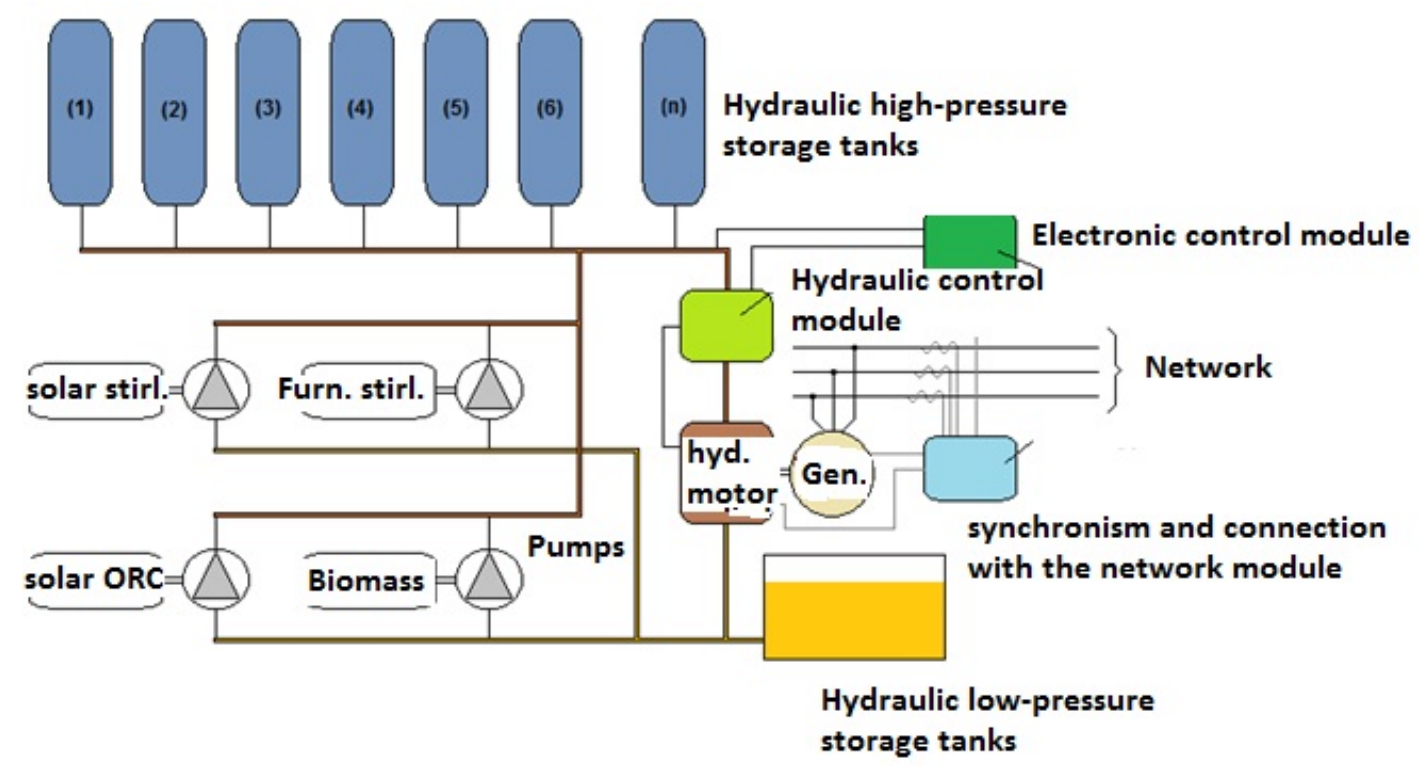

Fig. 3 Hydraulic integration system. 


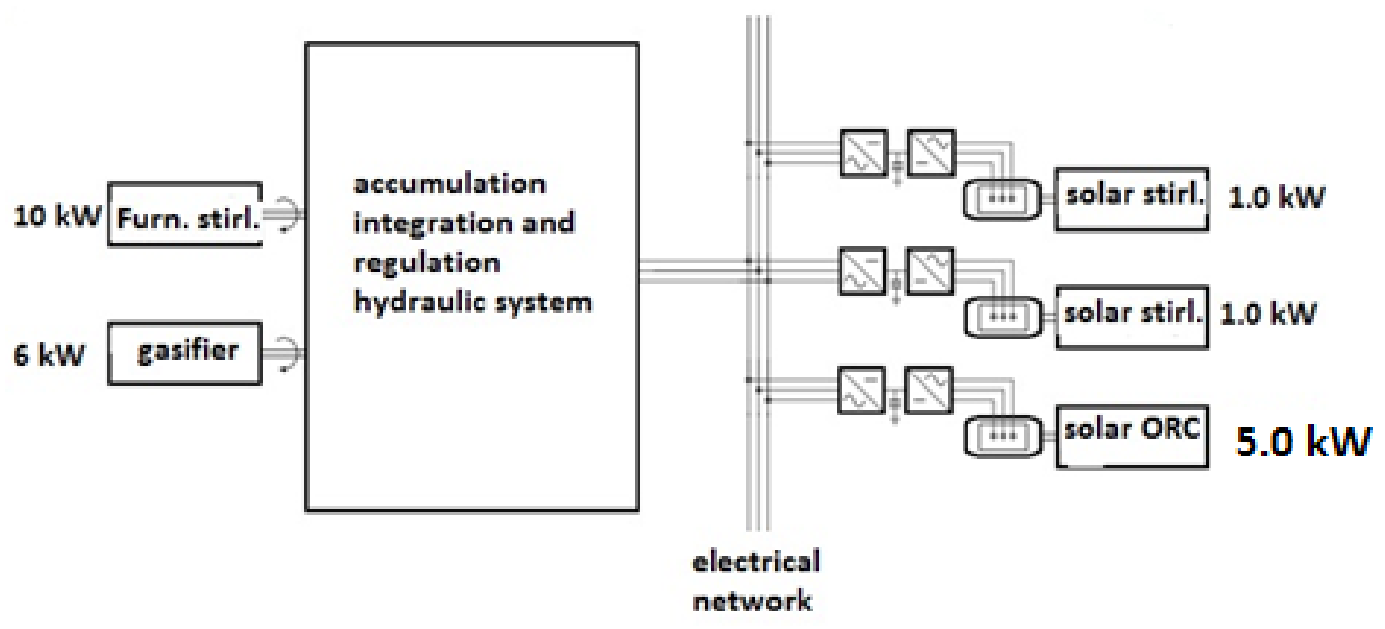

Fig. 4 Hydraulic-electric integration system.

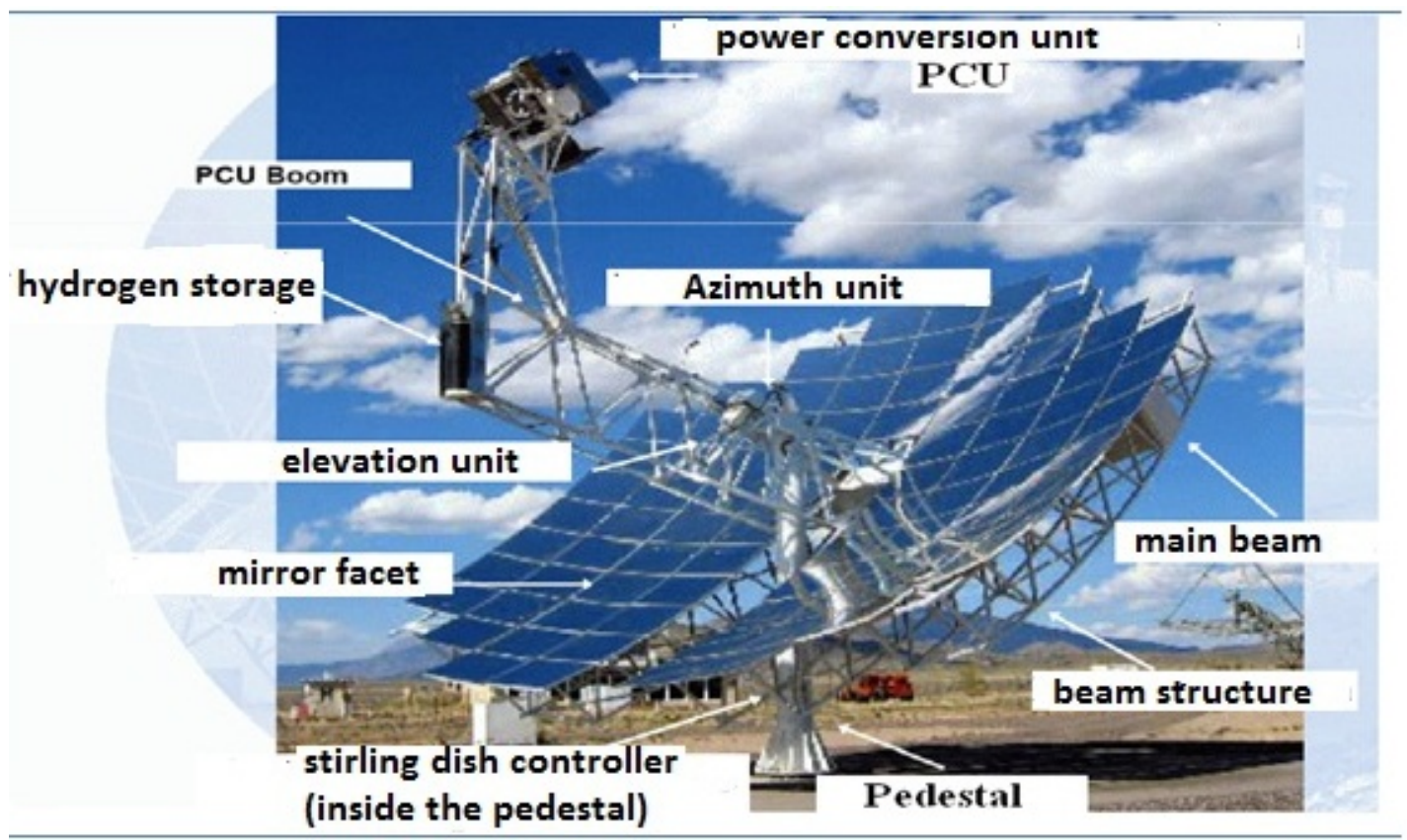

Fig. 5 Stirling solar dish.

\section{Conclusions}

The potential energy of the Sun is 24,000 times the world consumption, based on Brazil, a tropical country, has annual solar radiation and abundant biomass; integrate them into HSSB will be studied in the project. The use of intermittent sources of renewable energy, together with continuous renewable sources, using also a system of regulation/accumulation of energy is a very interesting strategy to ensure the attendance of the electricity demand in isolated systems and to contribute to meeting demand in interconnected system.

\section{Acknowledgments}

The authors would like to thank FAPEMIG (Foundation for Aid to Research of Minas Gerais State), for the financial support for the participation of one author in the conference, and also CPFL for the financial support for the development of the research work, project P \& D (research and development P \& D 0041, HSSB, project in partnership UNIFEI/FUPAI/CPFL/NEST_Light and Force Paulista Company-Campinas, Piratininga, S.P. Brazil—CPFL and Excellence Group in Thermal 
Power and Distributed—Generation-NEST).

\section{References}

[1] Andraka, C. E., Rawlinson, K. S., Moss, T. A., Adkins, D. R., Moreno, J. B., and Gallup, D. R. 1996. "Solar Heat Pipe Testing of the Stirling Thermal Motors 4-120.” In Proceedings of Energy Conversion Engineering Conference. IECEC, II, 1295-300.

[2] Bergermann, S., and GbR, P. 2001. EuroDish-Stirling System Description. Stuttgart: European Community under Contract.

[3] Dracke, R., and De Laquil III, P. 1996. "Progress Commercializing Solar-Electric Power Systems.” Rev. Energy Environ 21: 371-402.

[4] Electric Power Research Institute (EPR) and U.S Department of Energy 1997. Renewable Energy Technology Characterizations. Topical report, Washington, D.C.

[5] Burgess, G., Lovegrove, K., Coventry, J., Dennis, M., and Preston, J. 2006. Investigation of Combined Solar Thermal Power Generation and Desalination in the Murray Irrigation Limited Area of Operation. ANU Report number STG-TR-49, The Australian National University, Department of Engineering Australian National University Canberra ACT 0200, Canberra.

[6] Geyer, M. 2007. "Dish Stirling Activities at Schlaich Bergermann und Partner." Presented at Workshop at NREL, Germany.

[7] Johnston, G. 1995. "Flux Mapping the $400 \mathrm{~m} 2$ Big Dish at the Australian National University." Journal of Solar Energy Engineering 117: 290-2.

[8] Kalogirou, S. 2004. "Solar Thermal Collectors and Applications." Progress in Energy and Combustion Science 30: 231-95.

[9] Lovegrove, K., Burgess, G., McCready, D., and Pye, J. 2009. “ANU's New $500 \mathrm{~m}^{2}$ Paraboloidal Dish Solar Concentrator.” Solar Energy 85: 620-6.

[10] Lovegrove, K., Luzzi, A., Soldiani, I., and Kreetz, H. 2004. "Developing Ammonia Based Thermochemical Energy Storage for Dish Power Plants.” Solar Energy 76: 331-7.
[11] Lovegrove, K., Zawadski, A., and Coventy, J. 2007. "Paraboloidal Dish Solar Concentrators for Multi-megawatt Power Generation.” Presented at the Solar World Congress, Beijing, China.

[12] LTD, W. G. 2008. High Temperature Solar Thermal Technology Roadmap. Report for New South Wales and Victorian Governments.

[13] Mills, D. 2004. "Advances in Solar Thermal Electricity Technology.” Solar Energy 19-31.

[14] Mohamed, A., Bousaad, B., Noureddine, S., and Ahmed, C. 2011. "Dish Stirling technology: A 100 MW Solar Power Plant Using Hydrogen for Algeria.” International Journal of Hydrogen Energy 36: 4305-14.

[15] Mohan, N. 2012. Electric Machines and Drives-A First Course. USA: Wiley.

[16] Nepveu, F., Ferriere, A., and Bataille, F. 2009 "Thermal Model of a Dish/Stirling Systems.” Solar Energy 83: 81-9.

[17] Newton, C. C. 2007. "A concentrated Solar Thermal Energy System.” Dissertation, The Florida State University.

[18] Poullikkas, A., Kourtis, G., and Hadjipaschalis, I. 2010. "Parametric Analysis for the Installation of Solar Dish Technologies in Mediterranean Regions.” Renewable and Sustainable Energy Reviews 14 (9): 2772-83.

[19] Rezek, A. J. J. 2011, "Basic Fundaments of Electrical Machines-Tests and Theory.” Synergia (Rio de Janeiro), Acta, (Itajubá), editors, Brazil. (In Portuguese)

[20] Stephan R. M. 2013 "Electrical Machines, Driving, Command and Control.” Ciência Moderna, editor, Rio de Janeiro, R. J., Brazil. (In Portuguese)

[21] Stine, W. B., and Diver, R. B. 1994. A Compendium of Solar Dish/Stirling Technology. California: Sandia National Laboratories.

[22] Stone, K., Braun, H., Moore, M., \& Clark, T. 1997. “Stirling Energy Systems’ (SES)” Dish-Stirling Program, 1039-44.

[23] Trieb, F., Langnib, O., and Klaib, H. 1994. "Solar Electricity Generation-A Comparative View of Technologies, Costs and Environmental Impact." Solar Energy 59: 1-3.

[24] www.microgen-engine.com. 